\title{
EFS shows biallelic methylation in uveal melanoma with poor prognosis as well as tissue- specific methylation
}

\author{
Lisa C Neumann ${ }^{1}$, Andreas Weinhäusel ${ }^{2}$, Stefanie Thomas ${ }^{3}$, Bernhard Horsthemke ${ }^{1}$, Dietmar R Lohmann ${ }^{1}$ and \\ Michael Zeschnigk ${ }^{*}$
}

\begin{abstract}
Background: Uveal melanoma (UM) is a rare eye tumor. There are two classes of UM, which can be discriminated by the chromosome 3 status or global mRNA expression profile. Metastatic progression is predominantly originated from class II tumors or from tumors showing loss of an entire chromosome 3 (monosomy 3). We performed detailed EFS (embryonal Fyn-associated substrate) methylation analyses in UM, cultured uveal melanocytes and normal tissues, to explore the role of the differentially methylated EFS promoter region CpG island in tumor classification and metastatic progression.
\end{abstract}

Methods: EFS methylation was determined by direct sequencing of PCR products from bisulfite-treated DNA or by sequence analysis of individual cloned PCR products. The results were associated with clinical features of tumors and tumor-related death of patients.

Results: Analysis of 16 UM showed full methylation of the EFS CpG island in 8 (50\%), no methylation in 5 (31\%) and partial methylation in $3(19 \%)$ tumors. Kaplan-Meier analysis revealed a higher risk of metastatic progression for tumors with EFS methylation $(p=0.02)$. This correlation was confirmed in an independent set of 24 randomly chosen tumors. Notably, only UM with EFS methylation gave rise to metastases. Real-time quantitative RT-PCR expression analysis revealed a significant inverse correlation of EFS mRNA expression with EFS methylation in UM. We further found that EFS methylation is tissue-specific with full methylation in peripheral blood cells, and no methylation in sperm, cultured primary fibroblasts and fetal muscle, kidney and brain. Adult brain samples, cultured melanocytes from the uveal tract, fetal liver and 3 of 4 buccal swab samples showed partial methylation. EFS methylation always affects both alleles in normal and tumor samples.

Conclusions: Biallelic EFS methylation is likely to be the result of a site-directed methylation mechanism. Based on partial methylation as observed in cultured melanocytes we hypothesize that there might be methylated and unmethylated precursor cells located in the uveal tract. The EFS methylation of a UM may depend on which type of precursor cell the tumor originated from.

\section{Background}

$\mathrm{UM}$ is the most frequent primary intraocular tumor in adults. Two classes of UM have been defined that differ in chromosome 3 status, metastatic risk and global mRNA expression profiles [1,2]. As tumors with monosomy 3 are tightly associated with metastatic progression,

\footnotetext{
* Correspondence: michael.zeschnigk@uni-due.de

'Institut für Humangenetik, Universitätsklinikum Essen, Hufelandstr. 55, 45157 Essen, Germany

Full list of author information is available at the end of the article
}

chromosome 3 testing is used to predict patients' prognosis $[3,4]$. Recently, inactivating somatic mutations in the gene encoding BRCA1-associated protein 1 (BAP1) on chromosome $3 \mathrm{p} 21.1$ were found to be frequent only in those UM that showed expression profiles linked to high metastatic potential [5]. One possible explanation for the clinical and genetic dichotomy of UM is distinct cell lineage, meaning that the two tumor classes stem from different melanocytic precursor cells located in the uveal tract $[2,6]$. In this regard, many examples are

\section{Ciomed Central}


known where closely related terminally differentiated cells are characterized by distinct epigenetic patterns [7].

Most epigenetic studies in cancer focus on altered methylation of CpG islands (CGIs), which are found in the promoter regions of about $60 \%$ of all genes. With the exception of imprinted genes, genes on the inactive $\mathrm{X}$-chromosome in females, germline-specific genes as well as a few developmental genes, the cytosine residues within CGIs > 500 bp are mostly unmethylated [8,9]. It is commonly assumed that epimutations, like other genetic changes in cancer, develop in a random manner and are then selected for growth advantage to the mutant cell clone. For example, hypermethylation of promoter-associated CGIs can result in transcriptional silencing of tumor suppressor genes (TSG) [10]. In these instances - in line with the model of two hit inactivation - one mutational hit alters the methylation pattern of one allele and the second allele is either lost or inactivated by a structural mutation. However, CGI methylation is not necessarily the result of an epimutation. In recent years, an increasing number of nonimprinted, autosomal CGIs and CpG-rich regions have been identified that are already methylated in non-neoplastic cells $[8,9,11]$. In some regions, this kind of $\mathrm{CpG}$ methylation establishes long-term gene inactivation and is part of the process of cell differentiation from pluripotent embryonic stem cells to terminally differentiated somatic cells [12-14]. This process finally results in a cell type specific methylation pattern [7]. A potential link between cell differentiation and cancer is suggested by the observation that genes that are preferentially hypermethylated in cancer are often marked for transcriptional repression through association with polycomb group proteins in embryonic stem cells $[15,16]$.

Several methylation studies have been conducted to identify genes that, if hypermethylated, contribute to initiation and progression of UM [17-20]. Recently, we performed a comprehensive search for hypermethylation events in $16 \mathrm{UM}$ using a screening assay based on methylation-sensitive restriction digest of genomic DNA followed by PCR amplification and array based detection of 323 different CGIs. Preliminary results of this screening revealed a CGI located in the promoter region of the EFS gene with a methylation pattern that is very unusual for TSGs. This prompted us to perform a detailed methylation analysis on the EFS CGI in UM and normal tissues.

\section{Methods}

\section{Patients and specimens}

Fresh tumor and peripheral blood samples were obtained from patients with UM treated at the Ophthalmology Department of the University Hospital of Essen by primary enucleation without prior radiation or chemotherapy. All patients were given diagnoses according to current ophthalmologic criteria. Follow-up data including tumor-related cause of death are available from all patients. All tumors analyzed in this study were selected from a cohort of 262 tumors with either monosomy 3 or disomy 3 . The set of 16 tumors (set I) used to screen for and confirm altered methylation in UM was selected to equally represent tumors with monosomy 3 and disomy 3 . The chromosome 3 status of all tumors was determined by microsatellite analysis [21]. The second set of 24 tumors (set II) was randomly chosen from the same cohort of 262 tumors, excluding tumor set I. Tumor and blood samples were stored at $-80^{\circ} \mathrm{C}$ and $-20^{\circ} \mathrm{C}$, respectively. DNA from peripheral blood cells of patients and normal controls was extracted using the EZ1 DNA Blood $350 \mu \mathrm{l}$ Kit (Qiagen). RNA and DNA purification from primary tumors was performed as described elsewhere [2]. Uveal melanocytes were isolated from eyes that were obtained from anonymous individuals not diagnosed with UM and were cultured in medium containing G418 at concentrations toxic for non-melanocytic cells [22]. Primary skin fibroblasts were obtained from healthy donors and cultivated as described elsewhere [23]. DNA from fibroblasts and buccal swabs of healthy donors was extracted using the EZ1 DNA Tissue Kit (Qiagen). DNA material from various human tissues was provided by Ralf Hermann (fetal brain), Dirk Prawitt (fetal liver, kidney and muscle), Bernhard Zabel (adult brain) and Osman El-Maarri (sperm). The research followed the tenets of the Declaration of Helsinki and was approved by the institutional ethical committee. Informed consent was obtained from the tumor patients after detailed explanation of the nature and possible consequences of the study.

\section{Methylation analysis}

Bisulfite modification of DNA was performed using an established protocol with minor modifications [24]. Genomic DNA $(1-2 \mu \mathrm{g}$ in $50 \mu \mathrm{l})$ was denatured for 15 min at $37^{\circ} \mathrm{C}$ by adding $5.5 \mu \mathrm{l}$ of $3 \mathrm{M} \mathrm{NaOH}$. For complete denaturation, samples were incubated at $95^{\circ} \mathrm{C}$ for $2 \mathrm{~min}$ and immediately cooled on ice. The bisulfite solution was freshly prepared by dissolving $4.25 \mathrm{~g}$ of sodium bisulfite (Sigma) in $7.5 \mathrm{ml} \mathrm{H}_{2} \mathrm{O} .450 \mu \mathrm{l}$ of $50 \mathrm{mM}$ hydrochinone solution was added and the $\mathrm{pH}$ was adjusted to 5.15 by adding $0.5 \mathrm{ml}$ of $10 \mathrm{M} \mathrm{NaOH}$. The denatured DNA solution was mixed with $500 \mu \mathrm{l}$ of the bisulfite solution and incubated at $50^{\circ} \mathrm{C}$ for $16-20 \mathrm{~h}$ in the dark. The DNA was recovered using the Wizard DNA CleanUp System (Promega) followed by elution in $50 \mu \mathrm{l}$ prewarmed $\mathrm{H}_{2} \mathrm{O}\left(65^{\circ} \mathrm{C}\right)$. Subsequently, $5.5 \mu \mathrm{l}$ of $3 \mathrm{M} \mathrm{NaOH}$ was added and the samples were incubated for $15 \mathrm{~min}$ at $37^{\circ} \mathrm{C}$. The solution was then neutralized by adding 55 $\mu \mathrm{l}$ of $6 \mathrm{M} \mathrm{NH}_{4} \mathrm{OAc} \mathrm{pH}$ 7.0. The DNA was ethanol 
precipitated, washed in $70 \%$ ethanol, dried and resuspended in 15-30 $\mu \mathrm{l}$ of water depending on initial DNA input. To analyze the regions of interest, PCR was performed in a total volume of $25 \mu \mathrm{l}$ containing $3 \mu \mathrm{l}$ of bisulfite treated DNA, $0.2 \mathrm{mM}$ of each dNTP, $0.2 \mu \mathrm{M}$ of each primer, $2.5 \mu \mathrm{l} 10 \mathrm{x}$ PCR-Puffer, $2.5 \mathrm{mM} \mathrm{MgCl}_{2}$ and 1.5 U Taq Polymerase (AmpliTaq Gold, Applied Biosystems, Foster City, CA) using a GeneAmp 9700 system. A touch down protocol was adopted as follows [25]: After denaturation at $95^{\circ} \mathrm{C}$ for $5 \mathrm{~min}$, the annealing temperature was decreased $0.5^{\circ} \mathrm{C}$ every cycle from $63^{\circ} \mathrm{C}$ to $56^{\circ} \mathrm{C}$, at which temperature 35 cycles were carried out. For all cycles, annealing was performed for $1 \mathrm{~min}$, denaturation at $95^{\circ} \mathrm{C}$ for $20 \mathrm{sec}$ and extension at $72^{\circ} \mathrm{C}$ for 1 min, followed by a final extension at $72^{\circ} \mathrm{C}$ for $5 \mathrm{~min}$. To facilitate direct sequence analysis of PCR products from bisulfite-treated templates, GC-tagged primers were used containing additional nucleotides at the 5 ' end (indicated by bold letters) that do not bind to the template. The tags contain $\mathrm{C}$ and $\mathrm{G}$ nucleotides which are required for internal normalization during the Sanger sequencing [26]. Primer sequences: EFSfw: CTTGCTTCCTGGCACGAGTTTYGTTTTGGTTTT GTTTTAG; EFSrev: TGTAAAACGACGGCCAGTCATATTATCACTAAAACCAAAATCC. After agarose gel electrophoresis and purification using MinElute ${ }^{\mathrm{TM}}$ Gel Extraction Kit (Qiagen), sequence analysis was performed on an ABI 3100 automated capillary genetic analyzer (ABI) using Big Dye 1.1 (ABI) using a primer complementary to the tag sequence. EFS methylation was determined on the basis of all evaluable CpG positions in the analyzed region (11 CpGs located in the region chr14: 23835859-23835970 (GRCh37/hg19)). The analyzed region was classified as showing (i) full methylation if the $\mathrm{T}$ signal was absent or very low at every CpG position, (ii) no methylation in the absence of a $\mathrm{C}$ signal at every $\mathrm{CpG}$ position and (iii) partial methylation if both signals were present at some or all CpG positions (Figure 1). For sequence analysis of individual alleles, selected PCR products were cloned into the pGEM-T easy vector (Promega), according to manufacturer's instructions. This vector provides ready-to-use T-overhangs for ligation with A-overhangs of PCR-products. We cloned the same PCR products that had been analyzed by direct sequencing before and chose samples that showed partial methylation and that were informative for a SNP in the analyzed region (rs3759609). We picked 15-20 colonies per sample from which we isolated plasmid DNA using the Plasmid Mini Kit (Qiagen). The cloned fragments were sequenced using the SP6 Promoter Primer (Promega, Cat.\# Q5011) and aligned with the help of the BDPC web interface http://biochem.jacobs-university.de/BDPC/) [27]. Sequences from

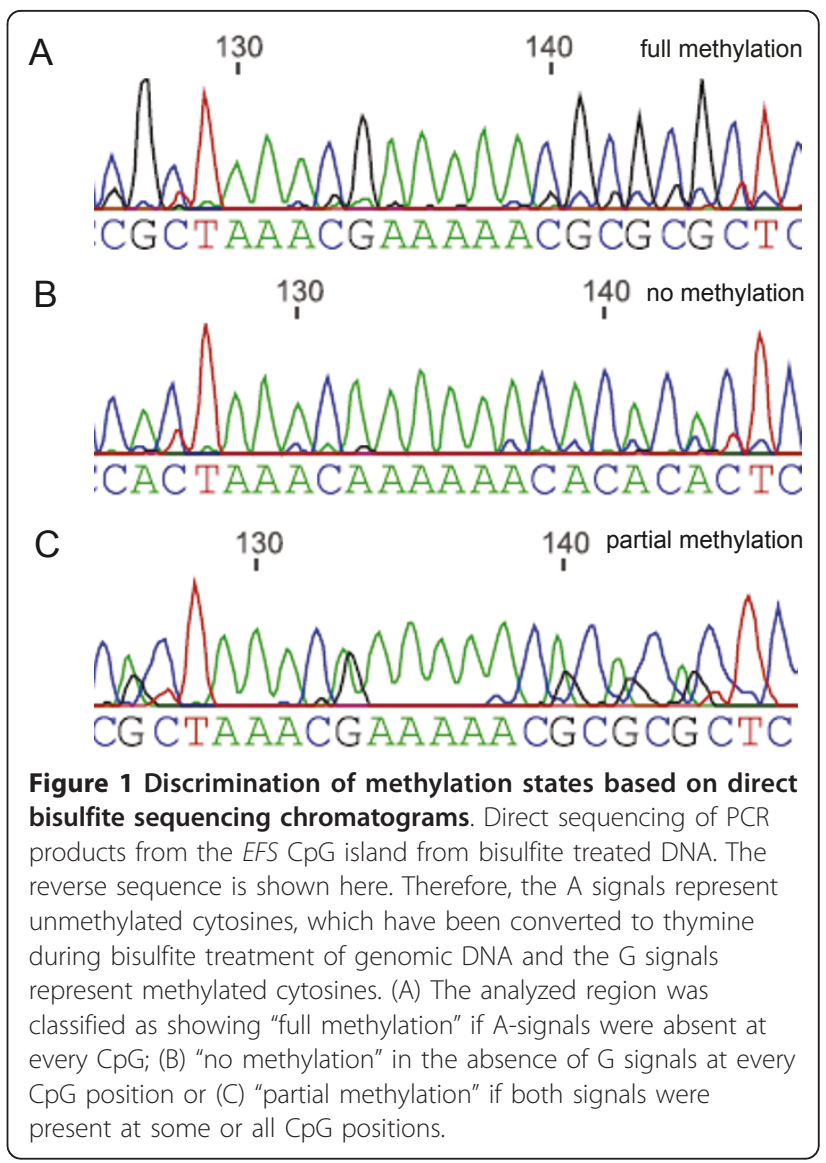

cloned EFS PCR products were analyzed in their full lengths (28 CpG positions).

\section{Real-time quantitative PCR}

EFS expression was analyzed by quantitative RT PCR using UPL-probe No. 17 (Universal probe library, Roche) and custom-designed primers (EFS-UPLProbe17fw: TCCTGAACTGCCCGAGAG; EFS-UPLProbe17-rev: GCATTGCCCAGCATAGAAGT). We used specific probes and primers for Human HPRT 1 (hypoxanthine phosphoribosyltransferase 1) as reference gene (Human HPRT1 Hs99999909_m1, ABI). An aliquot of $0.5 \mu \mathrm{g}$ total RNA was reverse transcribed using the GeneAmp RNA PCR Kit (ABI) according to the manufacturer's instructions. EFS quantitative RT-PCR was carried out in a volume of $20 \mu \mathrm{l}$ containing $10 \mu \mathrm{l}$ LightCycler 480 Probes Master, $2 \mu \mathrm{l}$ of cDNA, $0.3 \mu \mathrm{M}$ of UPL-probe No. 17 and $1 \mu \mathrm{M}$ of each primer. Amplification was performed with the Applied Biosystems 7000 Real-Time PCR System under the following conditions: $95^{\circ} \mathrm{C}$ for 10 min followed by 40 cycles of denaturation at $95^{\circ} \mathrm{C}$ for $15 \mathrm{sec}$ and annealing/elongation at $60^{\circ} \mathrm{C}$ for $1 \mathrm{~min}$. The mean value of duplicate samples was used for further analysis. Relative expression levels were calculated by 
the comparative Ct Method as described in the tutorial "Guide to Performing Relative Quantitation of Gene Expression Using Real-Time Quantitative PCR" (Part \#: 4371095 Rev B, Applied Biosystems).

Gene dosage analysis of EFS was performed by quantitative PCR using two independent assays located upstream (GRCh37/Hg19 position: chr14:23,836,13823,836,198) and downstream (GRCh37/Hg19 position: chr14:23,835,737-23,835,837) of the region used for methylation analysis. UPL-probe No. 55 (Universal probe library, Roche) was used for measurement of the PCR product generated with custom-designed primers: EFS-AMP2-UPLProbe55-fw: GATGTGGGGCTAATGAAAGG and EFS- AMP2-UPLProbe55-rev: GGTCCGATCGGCTTTCTC. Primers EFS-AMP1UPLProbe82-fw: AACTCCTGGTGGGGCTAGAT and EFS- AMP1-UPLProbe82-rev: GCTGGCACAAAAG TTGCTAGA were combined with UPL-probes No. 82. PCR was performed in a volume of $25 \mu$ l containing $12.5 \mu \mathrm{l}$ PCR Master Mix without AmpErase (ABI), 15 ng DNA, $0.25 \mu \mathrm{M}$ of UPL-probe and $0.4 \mu \mathrm{M}$ of each primer. As a reference, we used a region on the proximal long arm of chromosome 15 (GRCh37/hg19 position: chr15:25166001-25166074) [28]. Amplification was performed with a LightCycler 480 System (Roche) under the same conditions as described for expression analysis. All samples were measured in duplicate, and the mean value was used for further analysis. Relative gene dosage levels were calculated by the delta-delta- $C_{P}$ method with the LightCycler 480 software (Roche) using standard curves and normal control blood DNA for all assays.

\section{Data analysis}

Relationship between EFS expression and EFS methylation was evaluated using pair wise univariate chi-square test. Kaplan-Meier analysis was calculated using the Survival/Reliability tool of JMP ${ }^{\circledR}$ statistical discovery software (JMP 7. SAS, Heidenheim, Germany). To determine the possible correlation of EFS methylation with clinical variables univariate analysis was performed using the chi-square test. The Log-Rank test was performed to test the probability that there is a trend in survival scores across two groups in Kaplan-Meier analysis.

\section{Results}

We amplified the EFS CGI on bisulfite-treated DNA from $16 \mathrm{UMs}$ (set I), cultured uveal tract melanocytes and 10 blood samples from healthy donors. Methylation of the CGI was determined by direct sequencing of the PCR products. This technique provides an average methylation measurement for each CpG across the DNA molecules of a given sample. The CGI was classified either as showing full methylation, no methylation or partial methylation (Figure 1). We found the EFS CGI fully methylated in 8 tumors, unmethylated in 5 tumors and partially methylated in 3 tumors. EFS was also fully methylated in blood DNA from healthy donors and partially methylated in DNA from cultured melanocytes isolated from the uveal tract. Interestingly, EFS was fully methylated in all but one tumor with monosomy 3. In contrast, full methylation was only found in one of eight tumors with disomy 3 (set I, Table 1).

We analyzed the EFS genome dosage in all 8 tumors from set I that showed complete EFS methylation by quantitative RT-PCR to test whether complete methylation signals might be the result of monoallelic methylation on the background of a heterozygous EFS deletion. We found EFS genome dosage normal (two alleles) in all cases (data not shown), strongly suggesting biallelic EFS methylation.

Kaplan-Meier analysis was used to compare the outcome of patients. Survival analysis revealed a reduced disease free survival of patients with complete or partial EFS methylation in their tumor ( $\mathrm{p}=0.02$; Figure 2$)$. However, as the number of patients in set I was rather small, we analyzed another set of 24 tumors randomly chosen from a cohort of 246 tumor samples showing either monosomy 3 or disomy 3 . In this confirmatory group (set II), the significant correlation of EFS methylation and metastatic death of patients was confirmed ( $\mathrm{p}=$ 0.02). Notably, only tumors with EFS methylation gave rise to metastases. The correlation is more significant when combined analysis of tumors from set I and set II (40 tumors) is performed ( $\mathrm{p}=0.001$ ) and when tumors showing partial methylation are analyzed as separate group ( $\mathrm{p}=0.0004)$ (Figure 2 ).

Univariate analyses by pair wise comparison of EFS methylation with the variables listed in table 1 revealed a highly significant correlation of the EFS methylation with the chromosome 3 status $\left(\mathrm{p}=1.6 \times 10^{-6}\right)$ and cell type $(p=0.006)$. For the continuous parameters of tumors such as LBD (largest basal diameter), SBD (smallest basal diameter), prominence and patients' age at diagnosis we used a logistic model and found that LBD and age at diagnosis reached significance with $\mathrm{p}=$ 0.03 and $\mathrm{p}=0.02$, respectively.

We evaluated the possible correlation of EFS methylation and EFS expression by performing real-time quantitative RT-PCR on mRNA from the same set of tumors used for initial methylation analysis (set I; Figure 3). EFS expression was strongly reduced in tumors that showed complete EFS methylation compared to unmethylated tumor samples $(\mathrm{p}=0.008)$.

To address the possibility of tissue-specific EFS methylation indicated by the distinct methylation in blood cells and melanocytes we performed methylation analysis of various normal tissue samples and primary 
Table 1 Clinical data of the patients included in the study

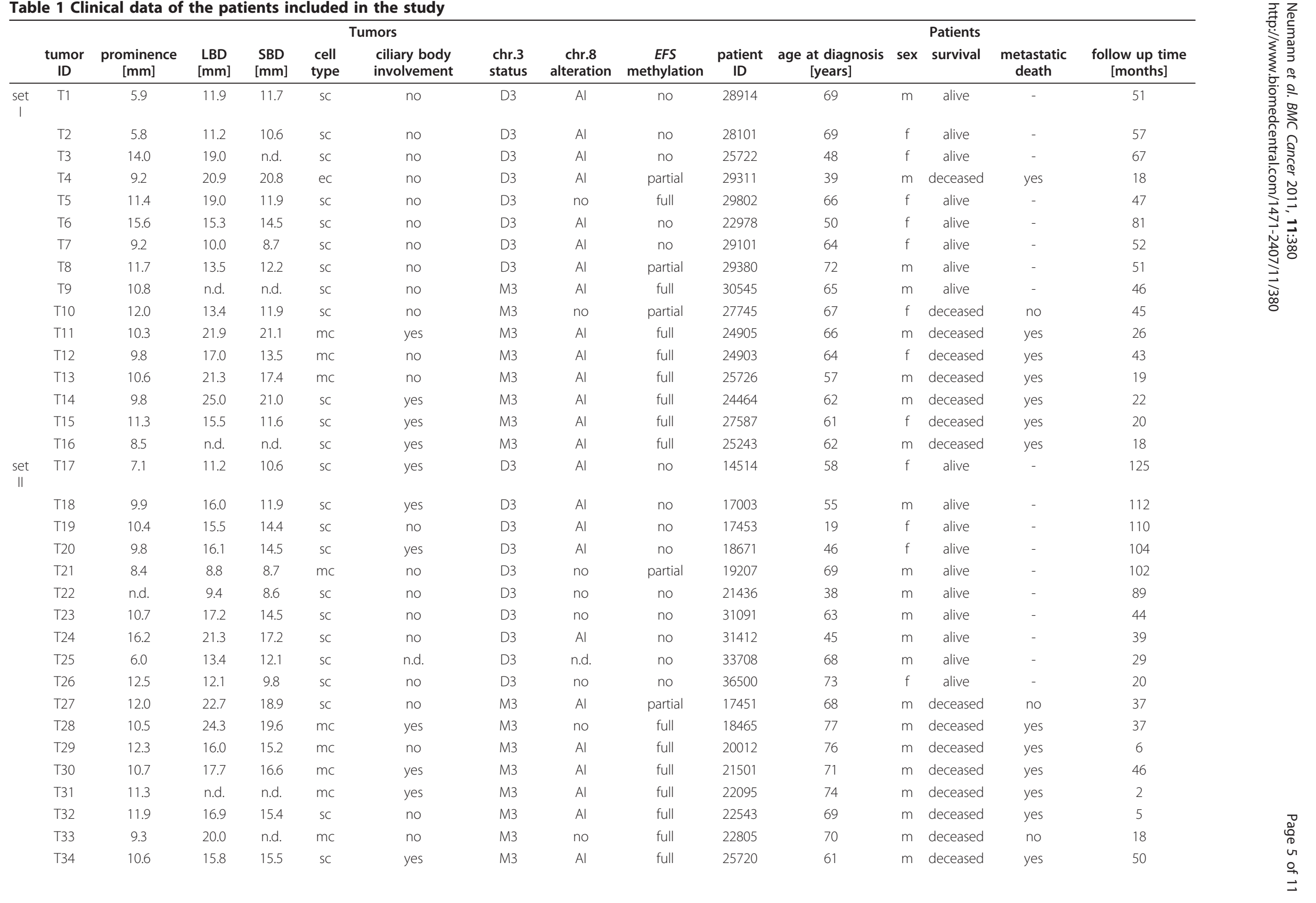


Table 1 Clinical data of the patients included in the study (Continued)

\begin{tabular}{|c|c|c|c|c|c|c|c|c|c|c|c|c|c|c|}
\hline T35 & 13.7 & n.d. & n.d. & SC & no & M3 & $\mathrm{Al}$ & partial & 26072 & 76 & $m$ & alive & - & 61 \\
\hline T36 & 11.3 & 11.4 & 7.0 & $\mathrm{mc}$ & yes & M3 & $\mathrm{Al}$ & full & 27766 & 63 & $\mathrm{~m}$ & deceased & yes & 35 \\
\hline T37 & 10.1 & 12.9 & 10.7 & sc & yes & M3 & $\mathrm{Al}$ & full & 29132 & 69 & f & alive & - & 52 \\
\hline T38 & 10.1 & 20.4 & 16.5 & sc & nd & M3 & no & full & 29337 & 74 & f & alive & - & 51 \\
\hline T39 & 13.6 & 18.0 & 14.5 & $\mathrm{mc}$ & no & M3 & $\mathrm{Al}$ & full & 32516 & 50 & $f$ & deceased & yes & 30 \\
\hline $\mathrm{T} 40$ & 8.3 & 12.5 & 11.5 & $\mathrm{mc}$ & no & M3 & $\mathrm{Al}$ & full & 34922 & 54 & $f$ & alive & - & 24 \\
\hline
\end{tabular}

Methylation status of EFS as determined by direct sequencing of PCR products from bisulfite treated DNA; LBD, largest tumor diameter; SBD, smallest tumor diameter; M3, monosomy 3; D3, normal (retention of both alleles) chromosome 3 status; Al, allelic imbalance; $m$, male; f, female; sc, spindle cell; mc, mixed cell; ec, epitheloid cell type; n.d., not determined. 


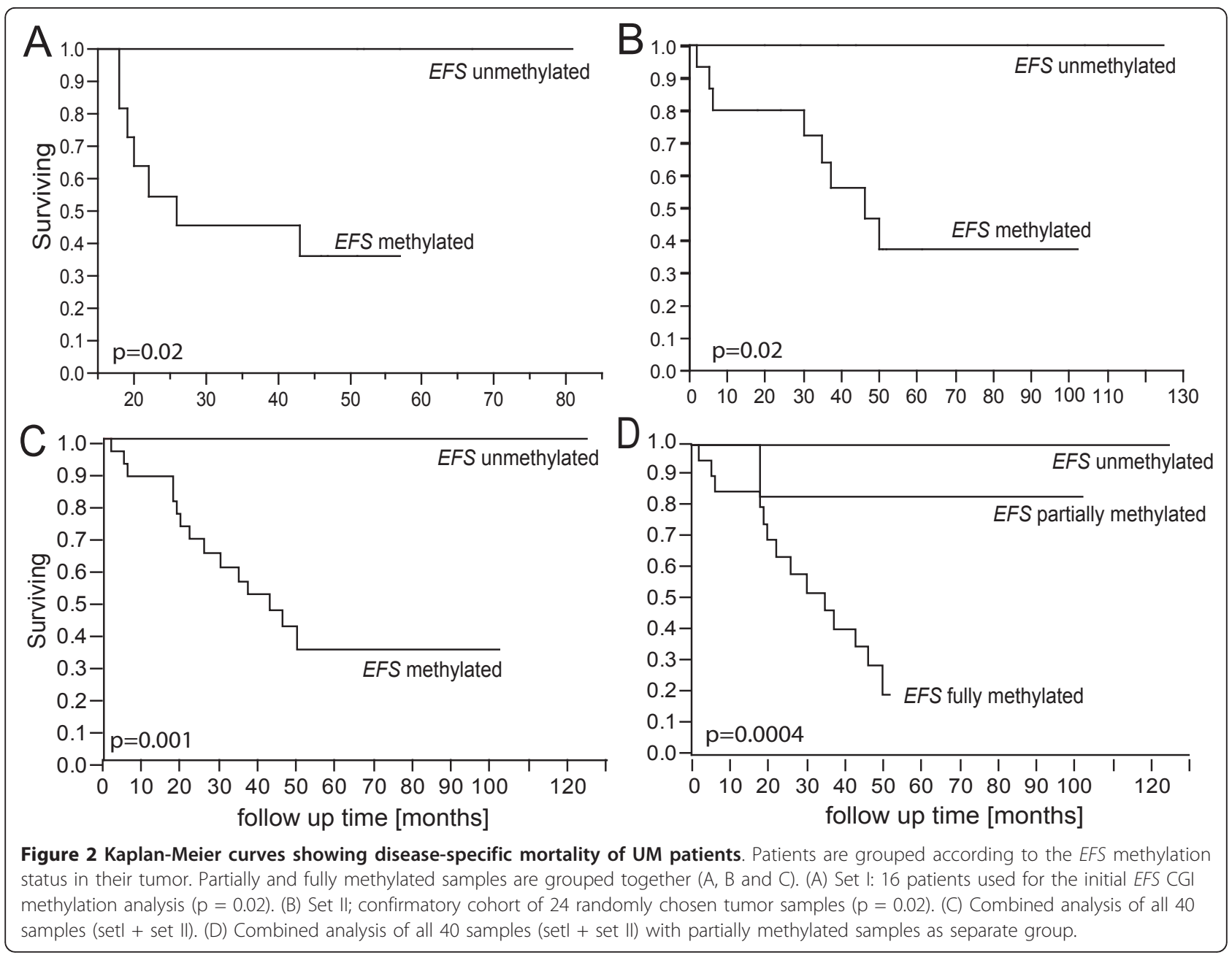

cells (Table 2). EFS was unmethylated in all sperm samples, most fetal tissues, cultured primary fibroblasts and one of four buccal swab samples. Complete methylation was observed in 13 of 15 blood samples from UM patients. Two blood samples from UM patients $\left(\mathrm{P}_{\mathrm{UM}} 1\right.$ and $\left.\mathrm{P}_{U M} 15\right)$, three buccal swab samples from normal donors and all adult brain samples showed the presence of methylated and unmethylated signals at all CpG dinucleotides, and thus, were classified as partially methylated.

To evaluate the nature of partial methylation in more detail we cloned PCR products from representative samples with partial EFS methylation and sequenced individual clones (Figure 4). Cloned PCR products represent the methylation pattern of a single allele and might facilitate discrimination between allele-specific methylation and incomplete methylation of both alleles. We chose samples informative for a polymorphism in the analyzed region (SNP rs3759609), which allows for allele discrimination. In one buccal swab sample, both alleles were found either methylated or unmethylated suggesting the presence of a mixture of methylated and unmethylated cells. Incomplete, but biallelic methylation was found in UM sample T10. In cultured melanocytes, EFS methylation was less dense, but still affected both alleles. Allele-specific EFS methylation was found in none of the samples.

\section{Discussion}

We found the methylation of the CGI located in the promoter region of $E F S$ to be biallelic in all nine UM samples analyzed in this respect (eight fully methylated and one partially methylated UM from set I). Such frequent biallelic methylation is unlikely to occur through random epimutations and suggests the action of a sitedirected de novo methylation mechanism, which is distinct from the two-step mutation-selection process that underlies allele-specific de novo hypermethylation of tumor suppressor genes. Tissue-specific methylation of EFS with full methylation in blood cells and partial or no methylation in most other tissues further argues for the involvement of such a methylation mechanism in 


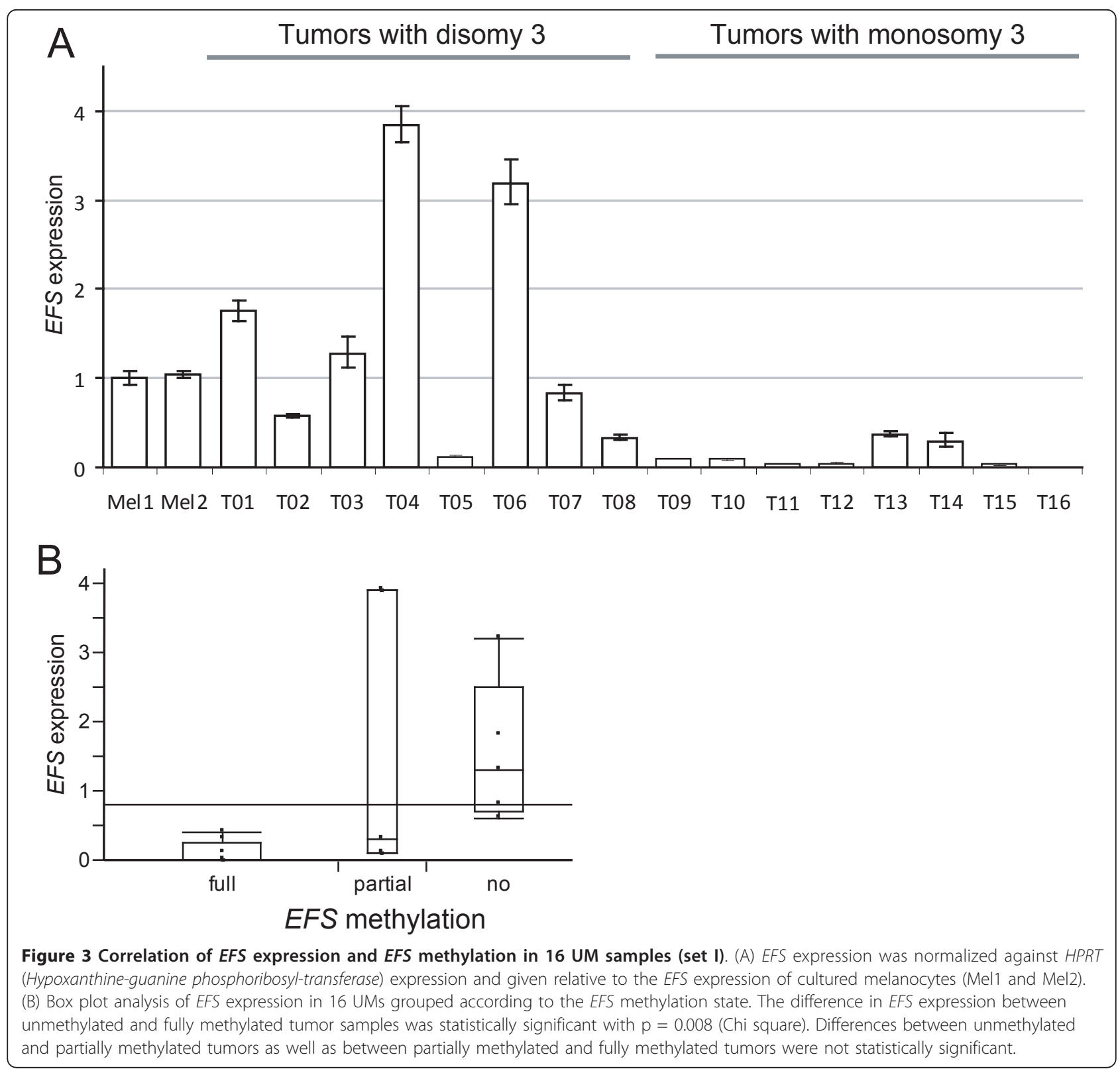

the differentiation of the hematopoietic cell lineage. Sitespecific methylation mechanisms, which may require the interaction of cis- and trans-acting factors, have been reported to be responsible for de novo methylation of tissue-specific methylated genes such as the POU5F1 pluripotency factor and are major components of cellular differentiation [12]. Most of the molecular components controlling this process are not yet known. With respect to $U M$, it would be interesting to find out if other genes are targeted by the same de novo methylation mechanism responsible for EFS methylation. Identification of these genes might provide further insight into the biological difference inherent to both uveal melanoma classes as methylation is strongly associated with metastatic progression.

The strong correlation of EFS methylation with transcriptional EFS silencing observed in UM shows that $E F S$ is subjected to long term inactivation by the methylation mechanism. The EFS promoter might therefore belong to the group of tissue-specific differentially methylated regions that contribute to tissue-specific transcription control [29].

We detected partial methylation in DNA from some normal tissue samples. Tissue heterogeneity might contribute to this observation as blood cells, which are methylated at EFS, are likely to contribute to the DNA 
Table 2 EFS methylation in different tissues and cell types

\begin{tabular}{lcccc}
\hline $\begin{array}{l}\text { Tissue/ } \\
\text { cell type }\end{array}$ & $\begin{array}{c}\text { Number of } \\
\text { samples }\end{array}$ & full & partial & no \\
\hline Blood & 10 & 10 & 0 & 0 \\
Blood (patients) & 15 & 13 & 2 & 0 \\
Melanocytes & 3 & 0 & 3 & 0 \\
Fibroblasts & 4 & 0 & 0 & 4 \\
Sperm & 2 & 0 & 0 & 2 \\
Buccal swab & 4 & 0 & 3 & 1 \\
Brain (adult) & 4 & 0 & 4 & 0 \\
Brain (fetal) & 1 & 0 & 0 & 1 \\
Kidney (fetal) & 1 & 0 & 0 & 1 \\
Muscle (fetal) & 1 & 0 & 0 & 1 \\
Liver (fetal) & 1 & 0 & 1 & 0
\end{tabular}

extracted from some tissue samples. Partial methylation was also found in cultured uveal melanocytes. As these cells were grown in geneticin at a concentration toxic for non-melanocytic cells, methylated EFS alleles are likely to be derived from melanocytes [22]. We cannot exclude that EFS methylation in these cells may have arisen in the course of cultivation. However, no EFS methylation was detected in cultured primary fibroblasts indicating that growing primary cells under cell culture conditions per se is not sufficient to induce EFS methylation. Analysis of individual clones representing individual alleles revealed CGI methylation of both parental EFS alleles (A and G allele; Figure 4B.), which argues for the existence of both methylated and unmethylated melanocytes in the uveal tract.

Genome and transcriptome analyses have shown that UMs fall into two classes that are congruent with high and low risk of death from metastatic disease [1,2]. Here we found that EFS methylation is significantly correlated with patients' survival and the chromosome 3 status of the tumors. In fact, all patients in our series who died of metastases showed EFS methylation in their primary tumors. Correlation of EFS methylation, although to a lesser extent, was also observed with the cell type, age at diagnosis and LBD. These parameters have previously been shown to correlate with monosomy 3 in UM suggesting that EFS methylation is a typical feature of the tumor class characterized by monosomy 3 .

From our data we cannot decide if the EFS methylation state was already present in tumor precursors or if it was acquired during tumorigenesis. Taking the differentially methylated melanocyte precursors into account, we propose that tumors with EFS methylation might be direct descendants from methylated precursors. Further progression of these tumors into a highly malignant

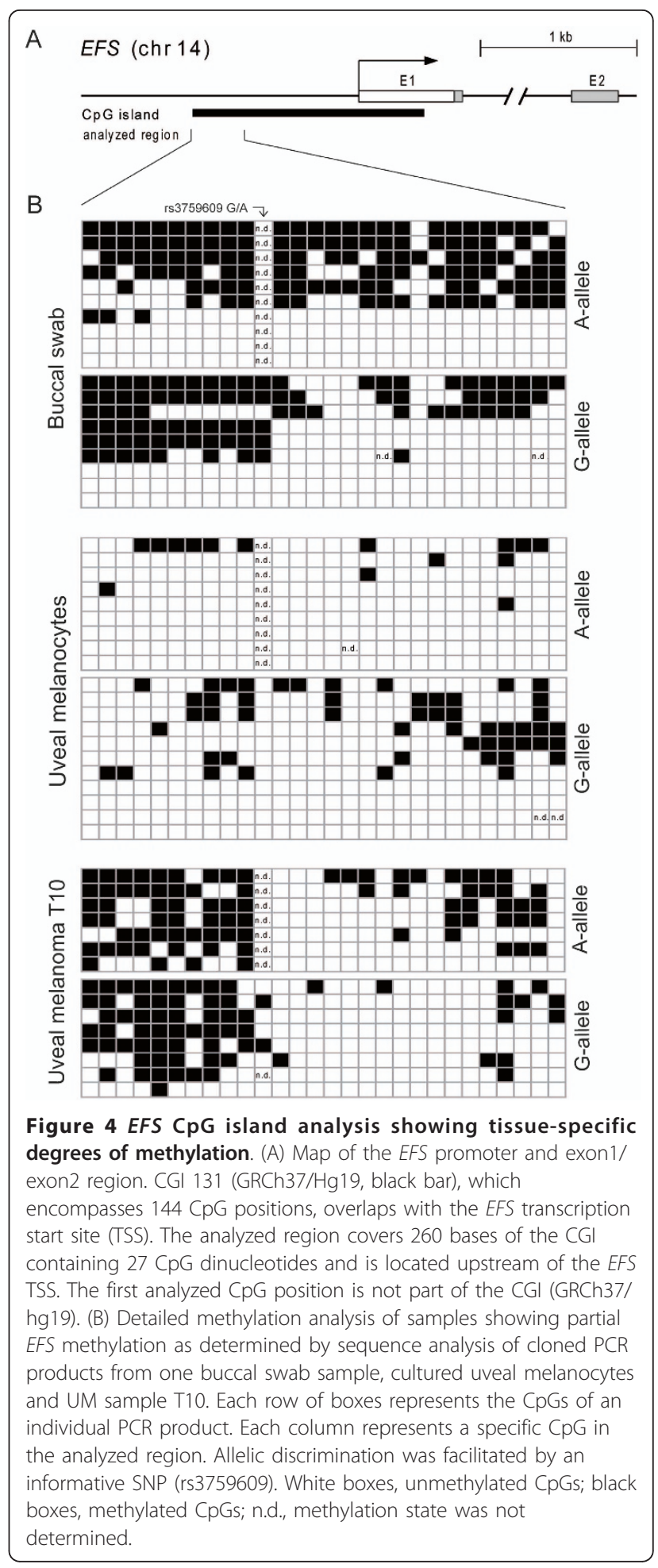

tumor phenotype might frequently, but not necessarily, be accompanied by loss of a chromosome 3 . This is in agreement with the idea of different melanocytic precursors as origin of the different classes of UM previously published by Tschentscher et al. and Chang et al. [2,6] 
Although EFS has been recognized as a member of the CAS protein family, little is known about its function so far. The protein contains a Src homology 3 (SH3) domain and has first been identified by interactions with the Src-family kinases Src, Fyn and Yes in mice [30,31]. Like other CAS family members EFS seems to act as an adapter protein, which is regulated by phosphorylation but has no enzymatic activities [32]. It was shown to be expressed in the thymic stroma [33] where it is involved in T-lymphocyte regulation and EFS-knockout mice develop exaggerated T-cell responses and inflammatory lesions [34]. EFS has not been linked to cancer, so far. However, other members of the CAS family can act as oncogenes and have been linked to metastasis and poor prognosis [32]. Involvement of the CAS proteins BCAR1 and NEDD9 in focal adhesions and mitotic spindle assembly, respectively, might hint towards implications of EFS in UM invasion or chromosome 3 loss.

\section{Conclusions}

Biallelic EFS methylation hints towards a site-specific methylation mechanism. Partial, but biallelic methylation in cultured melanocytes from the uveal tract suggests that there are methylated and unmethylated precursor cells. Therefore, EFS methylation of an UM may depend on which type of precursor cell the tumor originated from. It remains to be elucidated whether biallelic EFS methylation is established during progression of UM, or whether it mainly represents an early epigenetic flag that traces the two tumor classes back to their precursor cell. Identifying other genes targeted by the site-specific methylation mechanism might provide further insight into the biological difference underlying both UM classes.

\section{Acknowledgements and Funding}

We thank Caroline Pütter for statistical analysis of data, Lars Maßhöfer for technical assistance and Nicholas Wagner for proofreading the manuscript. This work was supported by the Deutsche Krebshilfe, 108612.

\section{Author details}

'Institut für Humangenetik, Universitätsklinikum Essen, Hufelandstr. 55, 45157 Essen, Germany. ${ }^{2}$ Austrian Research Center, Seibersdorf, Austria. ${ }^{3}$ Augenklinik, Universitätsklinikum Essen, Essen, Germany

\section{Authors' contributions}

LCN carried out most of the experiments and wrote the manuscript. AW carried out the preliminary hypermethylation study. ST supervised patients care and was involved in collecting follow up data. BH and DRL participated in the design of the study and helped to write the manuscript. MZ designed the study, performed the statistical analysis and wrote the manuscript. All authors read and approved the final manuscript.

\section{Competing interests}

The authors declare that they have no competing interests.

Received: 11 May 2011 Accepted: 26 August 2011

Published: 26 August 2011

\section{References}

1. Onken MD, Worley LA, Ehlers JP, Harbour JW: Gene expression profiling in uveal melanoma reveals two molecular classes and predicts metastatic death. Cancer Res 2004, 64:7205-7209.

2. Tschentscher F, Hüsing J, Hölter T, Kruse E, Dresen IG, Jöckel KH, Anastassiou G, Schilling H, Bornfeld N, Horsthemke B, Lohmann DR, Zeschnigk M: Tumor classification based on gene expression profiling shows that uveal melanomas with and without monosomy 3 represent two distinct entities. Cancer Res 2003, 63:2578-2584.

3. Prescher $G$, Bornfeld N, Hirche $H$, Horsthemke B, Jökel KH, Becher R: Prognostic implications of monosomy 3 in uveal melanoma. Lancet 1996, 347:1222-1225.

4. Damato B, Duke C, Coupland SE, Hiscott P, Smith PA, Campbell I, Douglas A, Howard P: Cytogenetics of uveal melanoma: a 7-year clinical experience. Ophthalmology 2007, 114:1925-1931.

5. Harbour JW, Onken MD, Roberson ED, Duan S, Cao L, Worley LA Council ML, Matatall KA, Helms C, Bowcock AM: Frequent mutation of BAP1 in metastasizing uveal melanomas. Science 2010, 330:1410-1413.

6. Chang SH, Worley LA, Onken MD, Harbour JW: Prognostic biomarkers in uveal melanoma: evidence for a stem cell-like phenotype associated with metastasis. Melanoma Res 2008, 18:191-200.

7. Floess S, Freyer J, Siewert C, Baron U, Olek S, Polansky J, Schlawe K, Chang HD, Bopp T, Schmitt E, Klein-Hessling S, Serfling E, Hamann A, Huehn J: Epigenetic control of the foxp3 locus in regulatory T cells. PLOS Biol 2007, 5:e38.

8. Takai D, Jones PA: Comprehensive analysis of CpG islands in human chromosomes 21 and 22. Proc Natl Acad Sci USA 2002, 99:3740-3745.

9. Zeschnigk M, Martin M, Betzl G, Kalbe A, Sirsch C, Buiting K, Gross S, Fritzilas E, Frey B, Rahmann S, Horsthemke B: Massive parallel bisulfite sequencing of CG-rich DNA fragments reveals that methylation of many $\mathrm{X}$-chromosomal CpG islands in female blood DNA is incomplete. Hum Mol Genet 2009, 18:1439-1448.

10. Greger V, Passarge E, Höping W, Messmer E, Horsthemke B: Epigenetic changes may contribute to the formation and spontaneous regression of retinoblastoma. Hum Genet 1989, 83:155-158.

11. Shen L, Kondo Y, Guo Y, Zhang J, Zhang L, Ahmed S, Shu J, Chen X, Waterland RA, Issa JP: Genome-wide profiling of DNA methylation reveals a class of normally methylated CpG island promoters. PLoS Genet 2007, 3:2023-2036

12. Deb-Rinker $P$, Ly D, Jezierski A, Sikorska M, Walker PR: Sequential DNA methylation of the Nanog and Oct-4 upstream regions in human NT2 cells during neuronal differentiation. J Biol Chem 2005, 280:6257-6260.

13. Illingworth R, Kerr A, Desousa D, Jorgensen H, Ellis P, Stalker J, Jackson D, Clee C, Plumb R, Rogers J, Humphray S, Cox T, Langford C, Bird A: A novel $\mathrm{CpG}$ island set identifies tissue-specific methylation at developmental gene loci. PLOS Biol 2008, 6:e22

14. Straussman R, Nejman D, Roberts D, Steinfeld I, Blum B, Benvenisty N, Simon I, Yakhini Z, Cedar H: Developmental programming of CpG island methylation profiles in the human genome. Nat Struct Mol Biol 2009, 16:564-571.

15. Ohm JE, McGarvey KM, Yu X, Cheng L, Schuebel KE, Cope $L$, Mohammad HP, Chen W, Daniel VC, Yu W, Berman DM, Jenuwein T, Pruitt K, Sharkis SJ, Watkins DN, Herman JG, Baylin SB: A stem cell-like chromatin pattern may predispose tumor suppressor genes to DNA hypermethylation and heritable silencing. Nat Genet 2007, 39:237-242.

16. Widschwendter M, Fiegl H, Egle D, Mueller-Holzner E, Spizzo G, Marth C, Weisenberger DJ, Campan M, Young J, Jacobs I, Laird PW: Epigenetic stem cell signature in cancer. Nat Genet 2007, 39:157-158.

17. Maat W, van der Velden PA, Out-Luiting C, Plug M, Dirks-Mulder A, Jager MJ, Gruis NA: Epigenetic inactivation of RASSF1a in uveal melanoma. Invest Ophthalmol Vis Sci 2007, 48:486-490.

18. Merhavi E, Cohen Y, Avraham BC, Frenkel S, Chowers I, Pe'er J, GoldenbergCohen N: Promoter methylation status of multiple genes in uveal melanoma. Invest Ophthalmol Vis Sci 2007, 48:4403-4406.

19. Moulin AP, Clement G, Bosman FT, Zografos L, Benhattar J: Methylation of CpG island promoters in uveal melanoma. Br J Ophthalmol 2008, 92:281-285.

20. Zeschnigk M, Tschentscher F, Lich C, Brandt B, Horsthemke B, Lohmann DR: Methylation Analysis of Several Tumour Suppressor Genes Shows a Low Frequency of Methylation of CDKN2A and RARB in Uveal Melanomas. Comp Funct Genomics 2003, 4:329-336. 
21. Tschentscher F, Prescher G, Zeschnigk M, Horsthemke B, Lohmann DR: Identification of chromosomes 3, 6, and 8 aberrations in uveal melanoma by microsatellite analysis in comparison to comparative genomic hybridization. Cancer Genet Cytogenet 2000, 122:13-17.

22. Hu DN, McCormick SA, Ritch R, Pelton-Henrion K: Studies of human uvea melanocytes in vitro: isolation, purification and cultivation of human uveal melanocytes. Invest Ophthalmol Vis Sci 1993, 34:2210-2219.

23. Fischer S, Lüdecke HJ, Wieczorek D, Böhringer S, Gillessen-Kaesbach G, Horsthemke B: Histone acetylation dependent allelic expression imbalance of BAPX1 in patients with the oculo-auriculo-vertebral spectrum. Hum Mol Genet 2006, 15:581-587.

24. Zeschnigk M, Lich C, Buiting K, Doerfler W, Horsthemke B: A single-tube PCR test for the diagnosis of Angelman and Prader-Willi syndrome based on allelic methylation differences at the SNRPN locus. Eur J Hum Genet 1997, 5:94-98.

25. Don RH, Cox PT, Wainwright BJ, Baker K, Mattick JS: 'Touchdown' PCR to circumvent spurious priming during gene amplification. Nucleic Acids Res 1991, 19:4008

26. Han W, Cauchi S, Herman JG, Spivack SD: DNA methylation mapping by tag-modified bisulfite genomic sequencing. Anal Biochem 2006, 355:50-61.

27. Rohde C, Zhang Y, Jurkowski TP, Stamerjohanns $H$, Reinhardt $R$, Jeltsch A: Bisulfite sequencing Data Presentation and Compilation (BDPC) web server-a useful tool for DNA methylation analysis. Nucleic Acids Res 2008, 36:e34.

28. Ronan A, Buiting K, Dudding T: Atypical Angelman syndrome with macrocephaly due to a familial imprinting center deletion. Am J Med Genet A 2008, 146A:78-82.

29. Ghosh S, Yates AJ, Fruhwald MC, Miecznikowski JC, Plass C, Smiraglia D: Tissue specific DNA methylation of CpG islands in normal human adult somatic tissues distinguishes neural from non-neural tissues. Epigenetics 2010, 5:527-538.

30. Ishino M, Ohba T, Sasaki H, Sasaki T: Molecular cloning of a cDNA encoding a phosphoprotein, Efs, which contains a Src homology 3 domain and associates with Fyn. Oncogene 1995, 11:2331-2338.

31. Alexandropoulos K, Baltimore D: Coordinate activation of c-Src by SH3 and $\mathrm{SH} 2$-binding sites on a novel p130Cas-related protein, Sin. Genes Dev 1996, 10:1341-1355.

32. Tikhmyanova N, Little JL, Golemis EA: CAS proteins in normal and pathological cell growth control. Cell Mol Life Sci 2010, 67:1025-1048.

33. Danzl NM, Donlin LT, Alexandropoulos K: Regulation of medullary thymic epithelial cell differentiation and function by the signaling protein Sin. $J$ Exp Med 2010, 207:999-1013.

34. Donlin LT, Danzl NM, Wanjalla C, Alexandropoulos K: Deficiency in expression of the signaling protein Sin/Efs leads to T-lymphocyte activation and mucosal inflammation. Mol Cell Biol 2005, 25:11035-11046.

\section{Pre-publication history}

The pre-publication history for this paper can be accessed here: http://www.biomedcentral.com/1471-2407/11/380/prepub

\section{doi:10.1186/1471-2407-11-380}

Cite this article as: Neumann et al: EFS shows biallelic methylation in uveal melanoma with poor prognosis as well as tissue-specific methylation. BMC Cancer 2011 11:380.

\section{Submit your next manuscript to BioMed Central and take full advantage of:}

- Convenient online submission

- Thorough peer review

- No space constraints or color figure charges

- Immediate publication on acceptance

- Inclusion in PubMed, CAS, Scopus and Google Scholar

- Research which is freely available for redistribution

Submit your manuscript at www.biomedcentral.com/submit
Biomed Central 